\title{
REPRODUCTION OF FEMALE FRANCISCANA (PONTOPORIA BLAINVILLEI) IN RIO GRANDE DO SUL, SOUTHERN BRAZIL
}

\author{
Daniel Danilewicz ${ }^{1,2,3}$
}

\begin{abstract}
In this paper, the reproductive biology of female franciscanas (Pontoporia blainvillei) is described based on a sample of 97 individuals collected in Rio Grande do Sul, southern Brazil. Data were collected from dolphins incidentally by-caught by the commercial fleet of Rio Grande and Tramandaí or stranded in the northern coast of Rio Grande do Sul. Age was estimated by counting the growth layer groups present in the dentin and cementum of the teeth. The female reproductive status was determined through the analysis of the ovaries, mammary glands and uterus. The large majority of the recorded ovulations occurred in the left ovary (88\%). There was no evidence that the corpus luteum (CL) increases its size as gestation progresses, and there is a considerable individual variation in CL size in females of different stages of pregnancy. The reproduction of the franciscana is markedly seasonal and the species present a typical birth-pulse pattern in Rio Grande do Sul. Births begin abruptly in October and decrease gradually until February. Length and weight at birth was estimated at $73.4 \mathrm{~cm}$ and $6.1 \mathrm{~kg}$, respectively, and the gestation period lasts 11.2 months. Mating and conception should occur between November and March. Sexual maturity in females is attained between 2 and 5 years. Estimation of mean age at sexual maturity was calculated as 3.7 years (CI 95\%=3.0-4.4 years) by the DeMaster method and 3.5 years by the logistic equation. Length and weight at sexual maturity were $138.9 \mathrm{~cm}(\mathrm{CI} 95 \%=132.8-145.1)$ and $32.8 \mathrm{~kg}(\mathrm{CI} 95 \%=29.9-35.7)$, respectively. Annual pregnancy rate in Rio Grande do Sul was estimated to be 0.66 , with a calving interval of 1.5 years. Due to its low age at sexual maturity, short calving interval and brief lifespan, the franciscana is one of the cetacean species with the fastest life history traits. There is no evidence of reproductive senescence and franciscanas seem to remain reproductively active throughout life.
\end{abstract}

Resumo - Neste trabalho a biologia reprodutiva das fêmeas de franciscanas (Pontoporia blainvillei) é descrita com base em uma amostra de 97 indivíduos coletados no Rio Grande do Sul, sul do Brasil. Os dados foram obtidos de animais acidentalmente capturados pela frota comercial de Rio Grande e de Tramandaí ou encalhados no litoral norte do Rio Grande do Sul. A idade foi estimada através da contagem dos grupos das camadas de crescimento ("growth layer groups") presentes na dentina e no cemento dos dentes. O estado reprodutivo das fêmeas foi determinado através da análise dos ovários, glândulas mamárias e útero. A maioria das ovulações registradas ocorreram no ovário esquerdo (88\%). Não foi encontrada nenhuma evidência de que o corpo lúteo (CL) aumente de tamanho a medida que a gestação progrida, havendo uma grande variabilidade individual no tamanho do CL em fêmeas de diferentes estágios de gestação. A reprodução da franciscana é caracteristicamente sazonal, apresentando um típico padrão de nascimentos em pulso no Rio Grande do Sul. Os nascimentos iniciam abruptamente em outubro e diminuem gradualmente até fevereiro. O tamanho e peso médio de nascimento foi estimado em $73.4 \mathrm{~cm}$ e $6.1 \mathrm{~kg}$, respectivamente, e o período de gestação dura 11.2 meses. O acasalamento e a concepção devem ocorrer entre os meses de novembro e março. A maturidade sexual nas fêmeas é atingida entre os 2 e 5 anos de idade. A idade média de maturidade sexual foi estimada em 3.7 anos (IC 95\%=3.0 - 4.4 anos) através do método de DeMaster e 3.5 anos através da equação logística. O comprimento e peso médio de maturidade sexual é de $138.9 \mathrm{~cm}$ (IC $95 \%=132.8-145.1)$ e $32.8 \mathrm{~kg}$ (IC 95\%=29.9-35.7), respectivamente. A taxa de prenhez anual foi estimada em 0.66 , com um intervalo reprodutivo de 1.5 anos. Nenhuma evidência de senescência reprodutiva foi encontrada, sugerindo que as franciscanas continuem reprodutivamente ativas até o final da vida.

Keywords: Franciscana, Pontoporia blainvillei, reproduction, life history, southern Brazil.

\section{Introduction}

The franciscana (Pontoporia blainvillei) is a dolphin endemic to the coastal waters of the Southwestern Atlantic Ocean. Its distribution ranges from Golfo Nuevo $\left(42^{\circ} 35^{\prime} S\right.$; $\left.64^{\circ} 48^{\prime} \mathrm{W}\right)$, Chubut Province, Argentina (Crespo et al., 1998) to Itaúnas $\left(18^{\circ} 25^{\prime} \mathrm{S} ; 30^{\circ} 42^{\prime} \mathrm{W}\right)$, Espiríto Santo, southeastern Brazil (Siciliano et al., 2002) (Figure 1).

The franciscana is susceptible to incidental catches in gillnets and trammel nets throughout most of its range (e.g. Praderi et al., 1989; Ott et al., 2002; Secchi et al., 2003). The species has been considered the most impacted small cetacean in the Southwestern Atlantic Ocean (Pinedo and Barreto, 1997; Secchi et al., 2002).

In the Rio Grande do Sul coast, southern Brazil, this species has been experiencing an intense bycatch in gillnets for at least three decades (Secchi et al., 1997; Moreno et al., 1997; Ott, 1998; Ott et al., 2002). The annual mortality of franciscanas in this region was estimated to be ranging from several hundreds up to around a thousand individuals (Secchi et al. 1997; Ott, 1998; Ott et al., 2002). The estimated bycatch rates are likely unsustainable (Secchi, 1999; Secchi et al., 2003). In this sense, it was agreed by the participants of the Fourth Workshop for the Coordinated Research and Conservation of the Franciscana Dolphin (Pontoporia blainvillei) in the Western South Atlantic (Porto Alegre, 2000) that the franciscana should be classified as Vulnerable (VU) instead of Data Deficient (DD) in the IUCN Red List of Threatened Species (Secchi et al., 2002).

${ }^{1}$ Grupo de Estudos de Mamíferos Aquáticos do Rio Grande do Sul (GEMARS). Rua Felipe Neri, 382/203, Porto Alegre, RS, 90440-150, Brazil. ${ }^{2}$ Centro de Estudos Costeiros, Limnológicos e Marinhos (CECLIMAR) \& Universidade Federal do Rio Grande do Sul (UFRGS). Av. Tramandaí, 976, Imbé, RS, 95625-000, Brazil.

${ }^{3}$ Laboratório de Dinâmica Populacional, Instituto de Biociências, Pontifícia Universidade Católica do Rio Grande do Sul. 


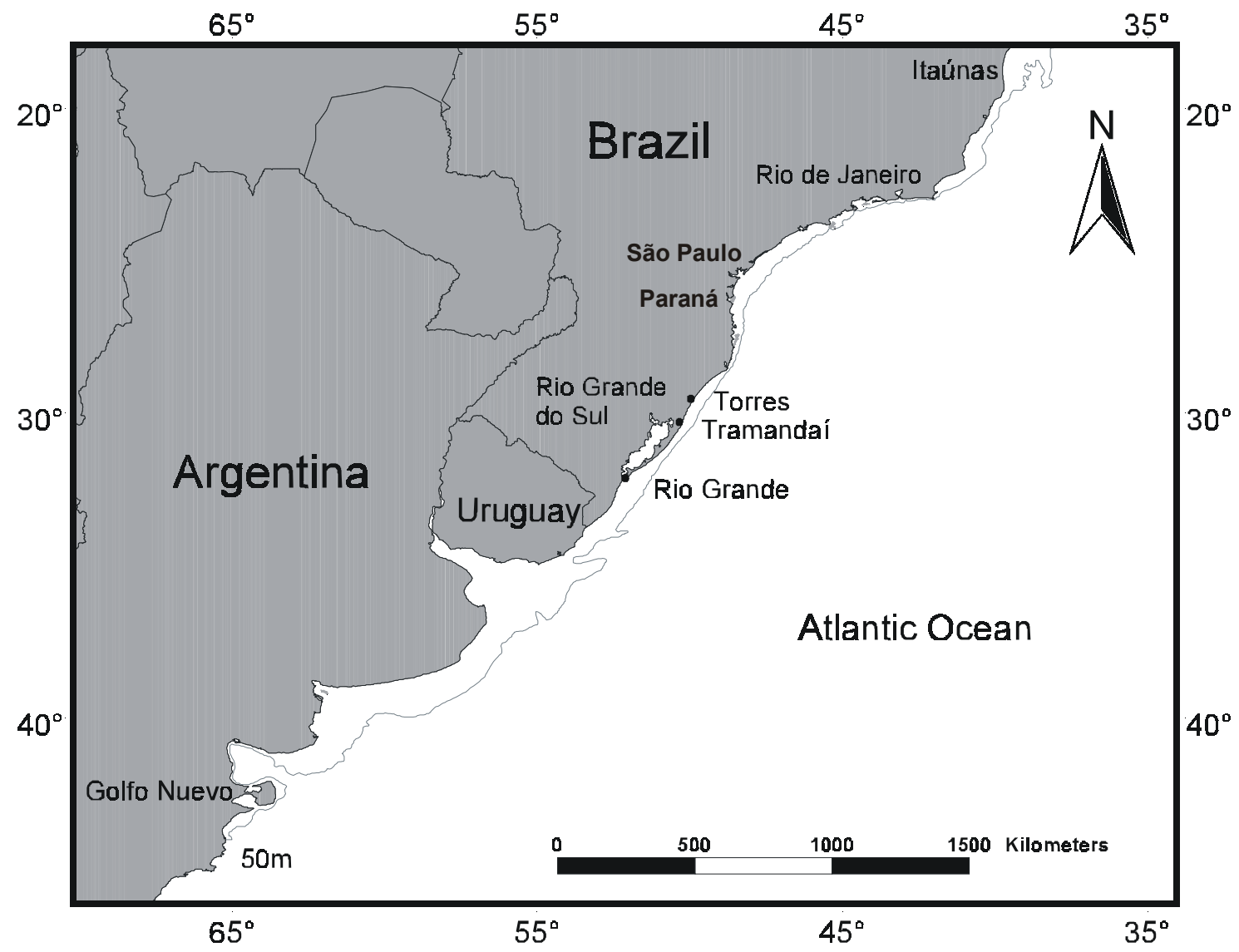

Figure 1. Map showing the distribution of franciscana, Pontoporia blainvillei, from Itaúnas, southeastern Brazil, to Golfo Nuevo, Argentina.

Reproductive studies of the franciscana are restricted to some localities of the species' range: Uruguay (Kasuya and Brownell, 1979; Harrison et al., 1981), Rio Grande do Sul (Danilewicz, 2000; Danilewicz et al., 2000; Danilewicz et al., in press), southern coast of São Paulo and Paraná (Rosas and Monteiro-Filho, 2001) and Rio de Janeiro (Ramos, 1997; Ramos et al., 2000). The first estimates of pregnancy rates and age at sexual maturity for female franciscanas off southern Brazil were published by Danilewicz et al. (2000), studying a sample of 50 animals from Rio Grande do Sul. The objective of this study was to describe the reproductive biology of female franciscanas from Rio Grande do Sul, yielding new estimates of age at sexual maturity and pregnancy rates based on a larger sample of animals. Furthermore, information on ovary characteristics, ovulation and mating time, gestation period, fetal growth, size at birth, and reproductive senescence is presented for franciscanas from this region.

\section{Material and Methods}

\section{Sampling procedures}

Data and samples collected from 97 specimens incidentally caught or stranded along the Rio Grande do Sul coast in the period 1992-1998 were used for the analysis. The sampling of incidentally caught animals was carried out through the monitoring of the gillnet fishing fleet operating from Rio Grande ( $\left.32^{\circ} 04^{\prime} \mathrm{S} ; 52^{\circ} 04^{\prime} \mathrm{W}\right)$ and Tramandaí/Imbé $\left(29^{\circ} 58^{\prime} \mathrm{S} ; 50^{\circ} 07^{\prime} \mathrm{W}\right)$. Stranded dolphins were sampled from systematic beach surveys conducted in an area of an extension of $270 \mathrm{~km}$ of sandy beaches, between Torres $\left(29^{\circ} 19^{\prime} \mathrm{S}, 49^{\circ} 43^{\prime} \mathrm{W}\right)$ and Lagoa do Peixe ( $\left.31^{\circ} 15^{\prime} \mathrm{S}, 50^{\circ} 54^{\prime} \mathrm{W}\right)$. Not all information could be collected from each carcass, so sample sizes vary between parameters. Standard length $(\mathrm{n}=97)$ was measured following the guidelines established by the American Society of Mammalogy (1961). The animals were weighed $(n=81)$ and teeth were extracted and preserved dried or in $70 \%$ alcohol. Ovaries were removed and fixed in $10 \%$ formalin. The mammary glands were examined to determine whether a female was lactating or not. The uterus was carefully examined for the presence of a fetus; particularly when a corpus luteum was observed in one of the ovaries. The length and mass of the fetuses were also measured.

\section{Age determination}

Age estimates were obtained from counts of growth layer groups in thin, longitudinal sections of teeth $(n=72)$. Franciscana teeth were decalcified in 5\% nitric acid or in RDO (a commercial acid) and sectioned on a freezing microtome. Sections $15-20 \mu \mathrm{m}$ thick were stained with Mayer's hematoxylin and mounted on microscope slides 
in Canadian balsam or in glycerin. Poor and off-center sections were discarded in favor of new preparations. Three readers counted the number of growth layer groups in the dentine and cementum independently. When estimates from the readers differed, the sections were reexamined together and agreed on a best estimate. In this paper, one GLG is considered to represent one year of age (Kasuya and Brownell, 1979; Pinedo, 1991; Pinedo and Hohn, 2000).

\section{Reproduction}

The ovaries were separated from the remains of the uterine horn and measured separately. After that, ovaries were examined externally for recording the presence or absence of corpus luteum, corpus albicans, and the largest follicles. To assure that all corpora resulting from an ovulation were recorded, the ovaries were sliced by hand to obtain sections $1-3 \mathrm{~mm}$ thick. The largest corpora and follicles were measured in three planes and the arithmetic mean of these measurements was called mean diameter.

The determination of the dolphin reproductive status followed the terminology recommended by the International Whaling Commission (Perrin and Donovan, 1984). Females with no corpora lutea (CL) or albicantia (CA) in the ovaries were classified as sexually immature. Females with at least one CL or CA in one ovary, denoting a past ovulation, were classified as sexually mature. Females were considered lactating if milk was detected in the mammary glands and the presence of a fetus in the uterus was used as criterion of pregnancy.

Gestation period and length at birth

Gestation period was estimated using the method of Huggett and Widdas (1951). This method utilizes the empirical concept that fetal growth in length is directly related to the gestation period and it is divided in two phases: a brief period of curvilinear growth $\left(t_{0}\right)$ and a posterior period of linear growth until birth. The duration of $\mathrm{t}_{0}$ can be derived from the equation provided by Calder (1982):

$$
\mathrm{t}_{0}=7.25 \mathrm{M}^{0.19} \quad \text { equation [1] }
$$

where $\mathrm{M}$ is the mean weight at birth (in grams). The linear phase is estimated applying the linear regression that describes the fetal growth.

To estimate the length at birth for the franciscanas, the mean length of the neonates collected only in October was calculated, since this is the month when births begin in the study region. Neonates were arbitrarily defined as animals smaller than $95.0 \mathrm{~cm}$ long, considering the length of the largest recorded franciscana fetuses.

\section{Attainment of sexual maturity}

Mean age at sexual maturity (ASM) was estimated using two different methods: (A) the DeMaster method (1978) and $(\mathrm{B})$ the age where $50 \%$ are mature as fitted by a logistic regression.
The DeMaster (1978) equation computes the mean as

$$
\mathrm{ASM}=\sum_{a=j}^{k} \mathrm{a}\left(\mathrm{f}_{a}-\mathrm{f}_{a-1}\right) \quad \text { equation [2] }
$$

where $\mathrm{f}_{a}$ is the fraction of sexually mature females with age $a, j$ and $k$ are the ages of the youngest sexually mature and the oldest sexually immature female, respectively.

The variance of the DeMaster method estimate is calculated as

$$
\operatorname{var}(\mathrm{ASM})=\sum_{a=j}^{k}\left[\left(\mathrm{f}_{a}\left(1=-\mathrm{f}_{a}\right) / \mathrm{N}_{a}-1\right] \quad\right. \text { equation [3] }
$$

where $\mathrm{N}_{a}$ is the total number of animals aged $a$.

The logistic regression approach fits a sigmoid curve, representing the probability that a franciscana of age $a$ is sexually mature, to the distribution of sexually mature and immature animals by age as

$$
\mathrm{Y}=1 /\left(1+\mathrm{e}^{\mathrm{xb+a}}\right) \quad \text { equation [4] }
$$

where $x$ is the age of the dolphin, $b$ is the slope of the regression and $a$ is the intercept. To obtain the age when $50 \%$ of the animals are sexually mature $(Y=0.5)$, the last equation is simplified as ASM $=-a / b$.

Mean length and weight at sexual maturity was also estimated by means of the DeMaster (1978) method, substituting age for length and weight, respectively. The method was slightly modified, as suggested by Ferrero and Walker (1993), and is represented as

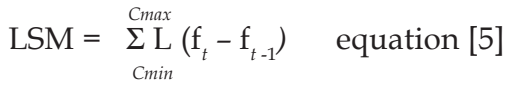

where Cmax is the length/weight class of the largest/ heaviest sexually immature animal, Cmin is the length/ weight class of the smallest/lightest sexually mature animal, $\mathrm{L}$ is the lower value of the length/weight class $t$, and $f_{t}$ is fraction of mature animals in the length/weight class $t$. The specimens were pooled in length and weight intervals of $4 \mathrm{~cm}$ and $4 \mathrm{~kg}$, respectively.

The estimated variance of this method is also modified and is calculated as

$$
\operatorname{var}(\mathrm{MS})=\mathrm{w}^{2} \sum_{C \text { min }}^{C \text { max }}\left[\left(\mathrm{f}_{i}\left(1-\mathrm{f}_{i}\right) / \mathrm{N}_{i}-1\right] \quad\right. \text { equation [6] }
$$

where $\mathrm{N}_{i}$ is the number of specimens in the length/weight class $t$, and $\mathrm{w}$ in the interval width.

\section{Annual pregnancy rate}

The annual pregnancy rate (APR) is expressed as the proportion of sexually mature females that were pregnant adjusted by the gestation time in years (Perrin and Reilly, 1984).

The approximate variance in APR was estimated by

$$
\operatorname{var}(\mathrm{APR})=\mathrm{APR}(1-\mathrm{APR}) / \mathrm{n} \quad \text { equation [7] }
$$

where $\mathrm{n}$ is the number of reproductive females in the sample. The calving interval was calculated as the reciprocal of the pregnancy rate (Perrin and Reilly, 1984):

$$
\mathrm{CI}=1 / \mathrm{APR} \quad \text { equation }[8]
$$




\section{Ovulation time}

The following criteria were utilized to detect a recent ovulation and to determine the ovulation time, as suggested by Harrison et al. (1981):

a) Presence of a recently ruptured follicle or a CL in early development;

b) Presence of a developed CL in a female carrying no embryo or fetus or with a distended uterus.

\section{Results}

\section{Ovary characteristics}

The weight of the ovary ranged from 0.08 to $1.25 \mathrm{~g}$ in immature (mean=0.33g) and from 1.07 to $9.5 \mathrm{~g}$ in mature females $($ mean $=4.9 \mathrm{~g}$ ). The relationship between ovary weight and standard length in immature and mature animals is presented in Figure 2.

No difference was detected between the weight of the right and left ovary in immature females $(t=-0.31$; d.f. $=24 ; \mathrm{P}=0.76$ ). Nevertheless, the left ovary is heavier in $89 \%$ of the mature animals, and this difference is significant $(t=-6.16$; d.f. $=23 ; \mathrm{P}>0.00001)$. This is the reflection of the higher number of corpora present in the left ovary $(88 \%)$. The majority of females $(71 \%)$ possessed corpora only in the left ovary.

The mean diameter of the CLs not associated with pregnancy (mean $=13.5 \mathrm{~mm}$ ) was significantly smaller than the one associated with pregnancy (mean $=19.0 \mathrm{~mm})(\mathrm{t}=2.87$, d.f. $=4, \mathrm{P}=0.045)$. Nevertheless, it was not possible to distinguish a gravid from a non-gravid CL based only on its morphology or size, as pointed out in several studies (e.g. Benirschke et al., 1980, Iwasa and Atkinson, 1996).

There is no evidence that the CL increases its size as gestation progresses. Although the slope of the linear regression between mean diameter of $\mathrm{CL}$ and fetal length is slight positive (Figure 3), it is not significantly different from $0\left(b=0.071 ; C I 95 \%=-0.066\right.$ to $\left.0.21 ; r^{2}=0.18 ; \mathrm{P}=0.26\right)$, and there is a considerable individual variation in CL size in females of different stages of pregnancy.

2

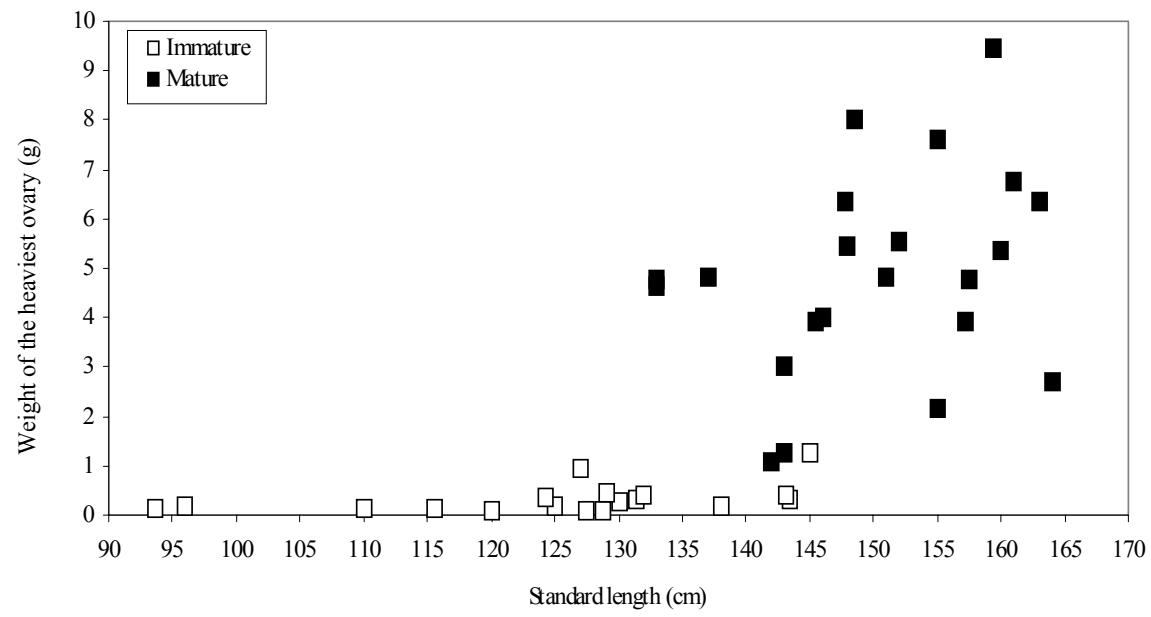

3

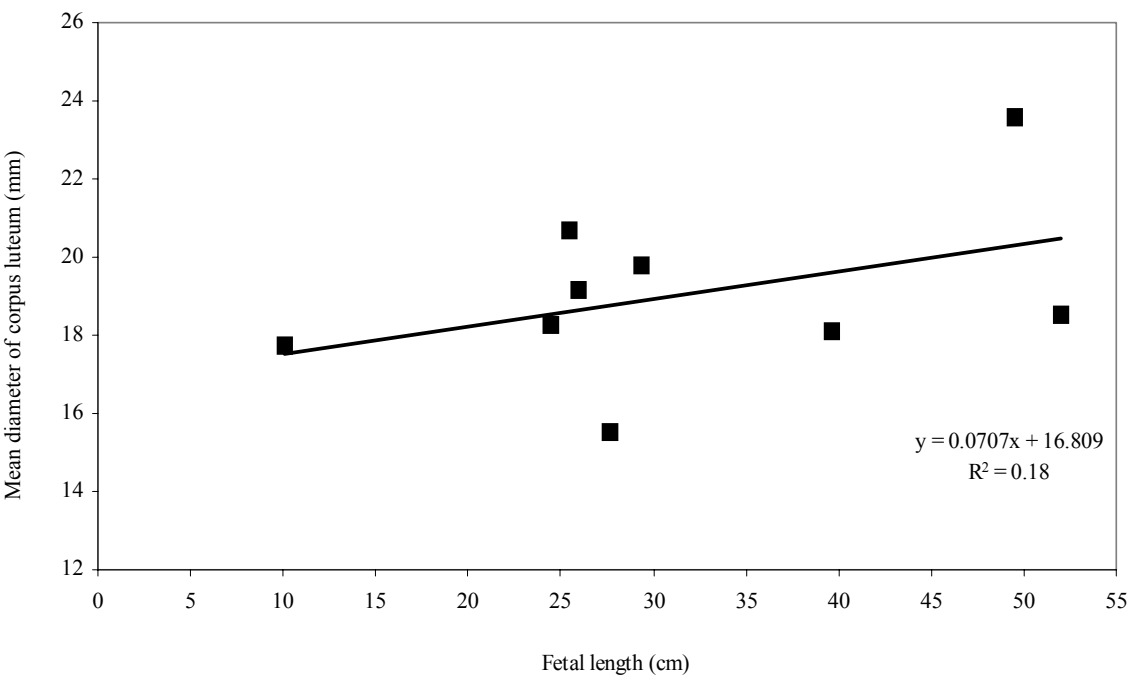

Figure 2. Relationship between standard length and weight of the heaviest ovary in immature and mature female franciscanas, Pontoporia blainvillei, from Rio Grande do Sul ( $\mathrm{n}=40$ ); figure 3. Relationship between mean diameter of corpus luteum and fetus length in franciscanas, Pontoporia blainvillei, from Rio Grande do Sul. 


\section{Gestation and births}

The fetus growth in relation to the months of the year (Figure 4) is described by a linear regression ( $F=94.5$, $\left.\mathrm{P}<0.001, \mathrm{r}^{2}=0.86, \mathrm{n}=18\right)$, represented by

$$
y=6.9445 x-9.1863 \quad \text { equation [9] }
$$

where $y$ is the fetus length $(\mathrm{cm})$ and $x$ represents the month of the year (January=1; December=12). Fetus growth in relation to the days of the year was also described by a linear regression $\left(\mathrm{F}=95.3, \mathrm{P}<0.001, \mathrm{r}^{2}=0.86, \mathrm{n}=18\right)$ and represented by

$$
\mathrm{y}=0.2436 \mathrm{x}-8.0574 \quad \text { equation [10] }
$$

where $y$ is the fetus length $(\mathrm{cm})$ and $x$ represents the day of the year ( 1 January $=1 ; 31$ December $=365)$. In this manner, the fetal growth rate is estimated to be $6.94 \mathrm{~cm} /$ month or $0.24 \mathrm{~cm} /$ day. Two outlier fetuses (open boxes in Figure 4) were not included in the calculus of this regression.

The species presents a typical birth-pulse pattern. Every year, the first neonates were collected in October, with the exception of an animal $67.0 \mathrm{~cm}$ long collected in 6 September 1997. The frequency of franciscana births in Rio Grande do Sul does not show a normal distribution. Instead, births begin abruptly in October and decrease gradually until February (Figure 5). The distribution of the relative frequency of neonates smaller than $85.0 \mathrm{~cm}$ suggests that about $75 \%$ of births occur from October to December.

The largest fetuses of the studied sample were 67.1, 75.0 and $84.0 \mathrm{~cm}$ long, and were collected in October, December and January, respectively. The smallest neonates measuring $67.0,67.5$, and two $70.0 \mathrm{~cm}$ long were collected in September, February and October $(n=2)$, respectively. The mean length at birth was estimated to be $73.4 \mathrm{~cm}$.

The presence of remains of the umbilical cord still attached to the animal is an efficient indication that it is a newborn. In the studied sample, three neonates with standard length of $67.5,70.0$ and $70.0 \mathrm{~cm}$ (mean $=69.2 \mathrm{~cm}$ ) were recorded with remains of the umbilical cord. It is important to note that former two were live stranded animals.

4

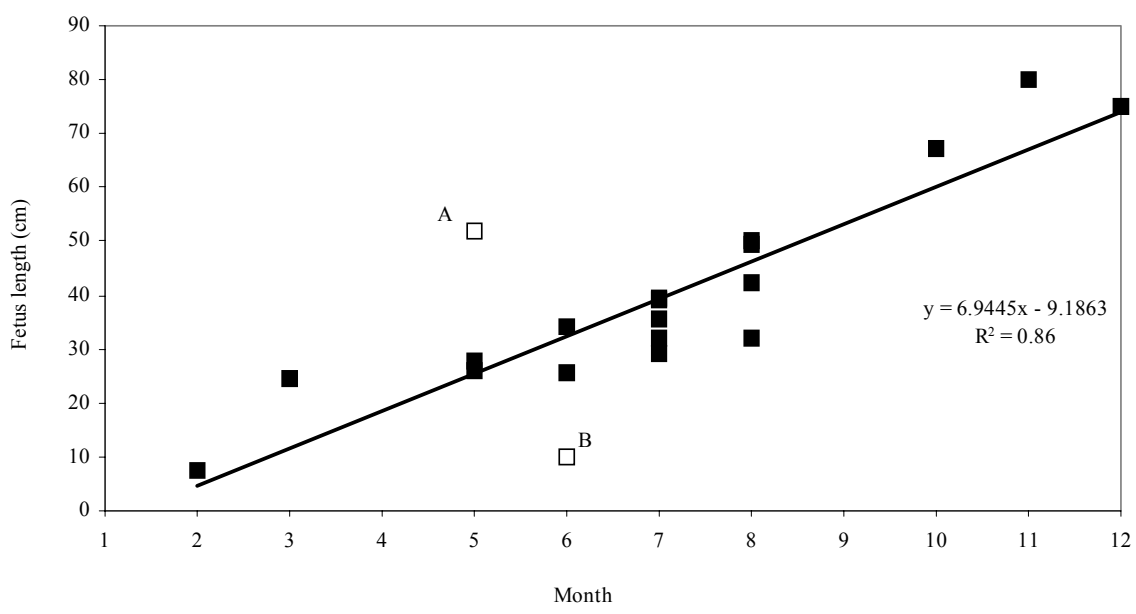

5

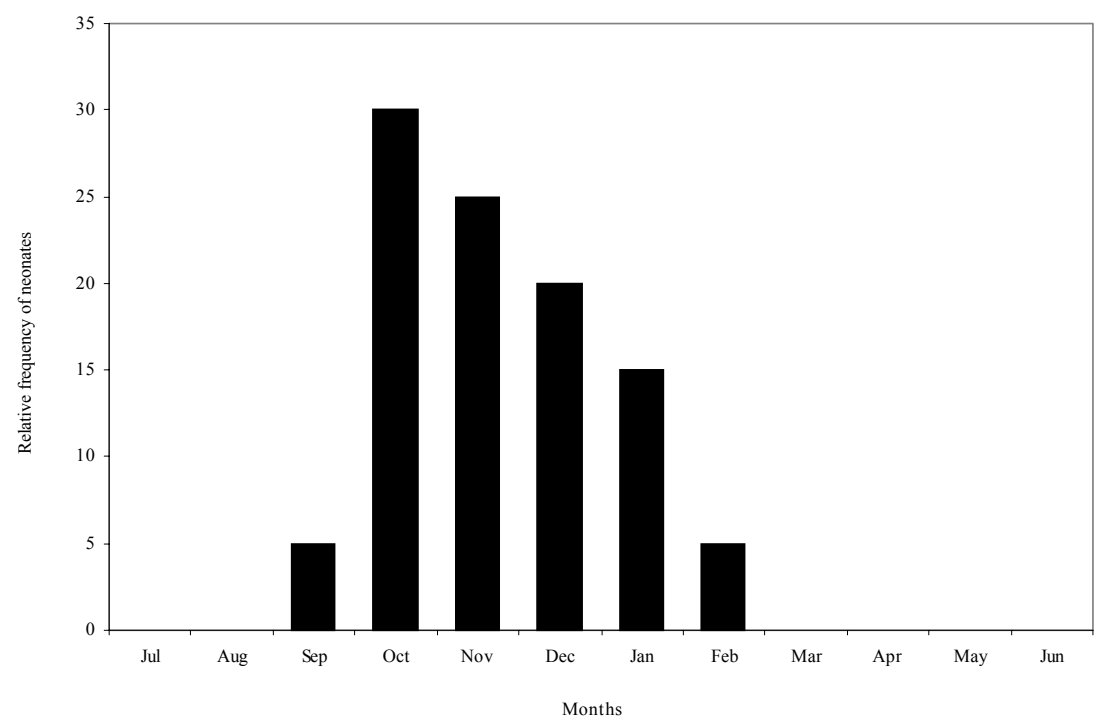

Figure 4. Linear regression of tetal length of tranciscanas, Pontoporia blainvillei, by month from January (1) to December (12). Open boxes represent 'outliers'; figure 5. Relative frequency of franciscana neonates along the year in Rio Grande do Sul. 
No multiplets were recorded $(n=20)$. Although the fetal sex ratio was slightly towards males (1.3; 8 males and 6 females), it does not differ significantly from $1\left(X^{2}=0.29\right.$, d.f. $\left.=1, P<0.05\right)$. The exponential relationship between fetal length and weight $\left(r^{2}=0.99\right)$ is shown in Figure 6 and is described by the equation

$$
\mathrm{y}=0.0827 \mathrm{e}^{0.0586 \mathrm{x}} \quad \text { equation [11] }
$$

From this equation, it is obtained a mean weight at birth of $6.1 \mathrm{~kg}$ for the length at birth $73.4 \mathrm{~cm}$.

The nonlinear phase of gestation was estimated substituting the mean weight of birth $(6.1 \mathrm{~kg})$ in the equation provided by Calder [1], and a period (to) of 38 days was obtained. In order to calculate the duration of the linear phase of gestation, equation [10] is solved for both date at birth (length at $73.4 \mathrm{~cm}$ ) and date at the start of linear growth (when fetal length is assumed to be 0 ), resulting in an estimate of 301 days. Thus, the entire duration of gestation is estimated to be 339 days $(301+38)$ or 11.2 months. Considering that births occur between October and early February and that gestation lasts for approximately 11 months, mating and conception should occur between November and early March.

Although gestation and births of franciscanas in Rio Grande do Sul are characterized by seasonality, two outliers A and $B$ (Figure 4) were recorded displaced from the fetal growth equation. Fetus $\mathrm{A}$ is displaced 3.5 months from fetal growth equation and its estimated conception and birth date are September 13 and August 19, respectively, while fetus B is displaced 3 months and its estimated conception and birth date are March 30 and March 4, respectively.

\section{Sexual maturity}

The sample of females with data on age and sexual maturity include 46 immature and 26 sexually mature dolphins. The oldest immature was 4 years old and the youngest mature were 3 years old, including some pregnant ones. Thus, sexual maturity is attained when females are between 2 and 5 years old (Table 1 , see discussion). The mean age at onset of sexual maturity for females was calculated as 3.7 years $(\mathrm{SD}=0.36$;
CI 95\%=3.0 - 4.4 years) by the DeMaster method and 3.5 years by the logistic equation. The mean age of seven females with only one corpus in the ovaries (i.e., collected in the year when they attained sexual maturity) was also 3.7 years $($ range $=3-6)$.

Table 1. Summary of information on age and reproduction of female franciscanas, Pontoporia blainvillei, in Rio Grande do Sul.

\begin{tabular}{lc}
\hline \hline VARIABLE & AGE \\
\hline \hline Age interval of females without corpora & $0-4$ \\
Youngest female with one corpus & 3 \\
Oldest female with one corpus & 6 \\
Youngest pregnant female & 3 \\
Oldest pregnant female & 11 \\
Youngest lactating female & 5 \\
Oldest lactating female & 11 \\
Oldest female of the sample & 19 \\
\hline \hline
\end{tabular}

The sample of females with data on length and sexual maturity include 62 immature and 32 sexually mature dolphins. The largest immature female was $149.9 \mathrm{~cm}$ long and the smallest mature was $133.0 \mathrm{~cm}$ long. Mean length at attainment of sexual maturity was estimated in $138.9 \mathrm{~cm}$ $(\mathrm{SD}=3.14 ; \mathrm{CI} 95 \%=132.8-145.1 \mathrm{~cm})$. The sample of females with data on weight and sexual maturity include 52 immature and 28 sexually mature dolphins. Mean weight at attainment of sexual maturity was estimated in $32.8 \mathrm{~kg}$ $(\mathrm{SD}=1.48 ; \mathrm{CI} 95 \%=29.9-35.7 \mathrm{~kg})$.

\section{Annual reproductive rate and calving interval}

Age-specific reproductive rates of franciscanas from Rio Grande do Sul are presented in Table 2. The estimated annual pregnancy rate was $0.66(95 \% \mathrm{CI}=0.47-0.85)$, with a variance of 0.0086 . The calving interval was estimate as 1.5 years $(95 \% \mathrm{CI}=1.2-2.1$ years $)$.

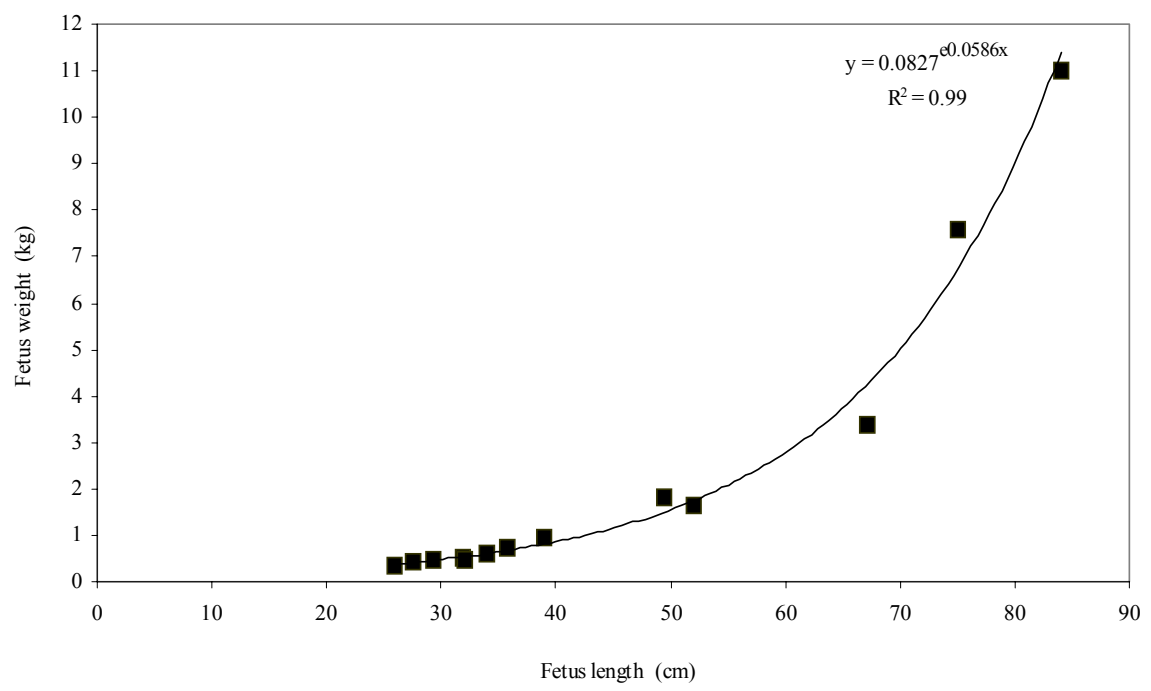

Figure 6. Relationship between length and weight of fetuses of franciscanas, Pontoporia blainvillei, in Rio Grande do Sul. 
Table 2. Age-specific reproductive rates of female franciscanas, Pontoporia blainvillei, in Rio Grande do Sul. $\mathrm{n}=$ sample size.

\begin{tabular}{crcccc}
\hline \hline AGE & N & MATURE & $\begin{array}{c}\text { PROPORTION } \\
\text { OF MATURE }\end{array}$ & PREGNANT & $\begin{array}{c}\text { PROPORTION } \\
\text { OF PREGNANT }\end{array}$ \\
\hline \hline 0 & 7 & 0 & --- & 0 & --- \\
1 & 23 & 0 & --- & 0 & -- \\
2 & 11 & 0 & --- & 0 & 0.63 \\
3 & 12 & 8 & 0.67 & 5 & 1.00 \\
4 & 3 & 2 & 0.67 & 2 & 0.67 \\
5 & 3 & 3 & 1.00 & 2 & 1.00 \\
6 & 4 & 4 & 1.00 & 4 & 0.33 \\
$7+$ & 9 & 9 & 1.00 & 3 & 0.62 \\
Total & 72 & 26 & 0.36 & 16 & 0 \\
\hline \hline
\end{tabular}

The low proportion of lactating females and of simultaneously pregnant and lactating females is contradictory to the high annual pregnancy rate found in this study. When the females experiencing their first pregnancy and that consequently could not be lactating are subtracted from the sample, the proportion of lactating and of simultaneously pregnant and lactating females is 0.3 and 0.1 , respectively.

The proportion of lactating females in the population is proportional to the time expended in the lactation (Perrin and Reilly, 1984), or:

$$
\mathrm{Lp}=\mathrm{Gp} \times(\mathrm{L} / \mathrm{P}) \quad \text { equation [12] }
$$

where $\mathrm{Lp}$ is lactation period in months, Gp is gestation period in months, $\mathrm{L}$ is the proportion of sexually mature females that are lactating and $\mathrm{P}$ is the proportion of sexually mature females that are pregnant.

In this manner, considering a lactation period of 9 months (Harrison et al., 1981), the proportion of pregnant females and the gestation period found in this study, it would be expected a proportion of 0.5 lactating franciscanas in the sample.

\section{Ovulation time}

Five females presenting ovaries with evidences of recent ovulation were collected in January, February $(n=2)$, June and August.

\section{Longevity and reproductive senescence}

The maximum age recorded for females in this study was 19 years. Evidence of reproductive senescence has been reported for some cetacean species by the observation of atrophic ovaries (i.e., ovaries of small size, with no recent ovulation and with atretic follicles) in old females, according to Perrin et al. (1976) and Marsh and Kasuya (1984). No animal analyzed in this study presented such characteristics. Some older females (two 10 yr-old, one 11 yr-old, and one $19 \mathrm{yr}$-old) were still reproductively active.

\section{Discussion}

The tendency of a much higher activity of the left ovary has been well documented in P. blainvillei (e.g. Harrison et al.,
1981, Brownell, 1984). In Uruguay, no mature female studied $(n=43)$ presented corpora in both ovaries simultaneously, and only two of them had corpora in the right ovary (Brownell, 1984). Interestingly, no ovulation polarity was observed in franciscanas from the southern coast of São Paulo and Paraná, with both right and left ovaries being functional (Rosas and Monteiro-Filho, 2001).

Although in some marine mammal species the corpus luteum increases its size as gestation progress (e.g. Boyd, 1984), there is not a clear pattern among cetaceans. It was demonstrated that in the pantropical spotted dolphin, Stenella attenuata, and in the striped dolphin, $S$. coeruleoalba, the CL decreases during gestation (Perrin et al., 1976; Miyazaki, 1977), and in the short-finned pilot whale it does not suffer significant changes in size during gestation (Marsh and Kasuya, 1984). Data from this study does not indicate an increase of the CL as the franciscana gestation progresses, and CL size alone must not be used as an indicator of gestation time. Harrison et al. (1981) analyzed a larger sample $(n=33)$ of pregnant females and also recognized a high individual variation of $C L$ in relation to gestation time. Nevertheless, a slight increase in its size during the gestation could be noticed.

Gestation period is one of the reproductive parameters with less intraspecific variation among mammals (Kiltie, 1982). In most cetacean species gestation lasts about 10-12 months (Lockyer, 1984; Perrin and Reilly, 1984). As exceptions, the following could be cited: the sperm whale, Physeter macrocephalus (16-17 months, Harrison, 1969), the Baird's beaked whale, Berardius bairdii (17 months, Kasuya, 1977), the pilot whales, genus Globicephala (15 months (Kasuya and Marsh, 1984) and the killer whale, Orcinus orca (15 months, Perrin and Reilly, 1984). The gestation period estimation of 11.2 months obtained for the franciscana in this study is very similar to those estimated in other study sites. In Uruguay, Harrison et al. (1981) estimated a gestation period of 10.5-12 months (probably closer to 10.5 months), and Kasuya and Brownell (1979) studied the same sample and estimated it as 10.8-11 months. Along the Brazilian coast, gestation was calculated to last 10.6 months in Paraná/southern São Paulo (Rosas and Monteiro-Filho, 2001) and 10.2-10.4 months in Rio de 
Janeiro (Ramos, 1997). These last values are the smallest for the species and may be influenced by the estimator: the linear regression given Perrin et al. (1977) and applied by Ramos tends to produce shorter estimations of gestation length than the Huggett and Widdas (1951) method, even when the same values of length at birth are used in the calculation.

The fetal growth rate of the linear phase of gestation is higher in Rio de Janeiro $(7.6 \mathrm{~cm} / \mathrm{month})$ than in Rio Grande do Sul $(6.94 \mathrm{~cm} / \mathrm{month})$. This difference is also likely the result of using distinct methods to calculate gestation length rather than a reflection of real differences in fetus growth pattern.

It is considered here that the mean length and weight at birth of $73.4 \mathrm{~cm}$ and $6.1 \mathrm{~kg}$, respectively, are the most accurate for the population of franciscanas from Rio Grande do Sul, since it considers only the neonates collected in the first month of parturition in the region (October), and decreases the probability of including older animals in the calculation.

Adult franciscanas from Rio Grande do Sul are remarkably larger than those from Paraná, São Paulo and Rio de Janeiro. While asymptotic lengths of males and females from the former region range from $129.8-136.4 \mathrm{~cm}$ and $146.4-161.9 \mathrm{~cm}$, respectively, the asymptotic lengths of males and females from the later regions range from $113.3-117.1 \mathrm{~cm}$ and $128.9-144.7 \mathrm{~cm}$ (Kasuya and Brownell, 1979; Walter, 1997; Ramos et al., 2000; Rosas and Monteiro-Filho, 2001). Thus, it could be expected that length at birth would also be larger in Rio Grande do Sul. However, length at birth in Rio de Janeiro $(71.0 \mathrm{~cm})$ and Paraná/southern São Paulo $(71.2 \mathrm{~cm})$ is almost the same as in Rio Grande do Sul and very similar to the values for Uruguay found by Harrison et al. (1981) (closer to $70.0 \mathrm{~cm}$ ) and Kasuya and Brownell (1979) (70.0 - 75.0cm), demonstrating the birth size does not present variation in this species. The smallest neonate reported for Rio de Janeiro was $66.0 \mathrm{~cm}$ long, while in Rio Grande do Sul the smallest neonate measured $67.0 \mathrm{~cm}$ in length. On the other hand, the largest fetus in Rio de Janeiro measured $65.0 \mathrm{~cm}$, while in Rio Grande do Sul it measured $80.0 \mathrm{~cm}$. This marked difference may suggest that the range of length at birth is considerably wider in Rio Grande do Sul.

Many mammalian species exhibit a reproductive seasonality, presenting a well-defined period for mating and births. This seasonality is generally associated with a higher offspring survival from females that give birth within the reproductive peak than those who give birth outside the peak (Majluf, 1992). The franciscana reproduction in Rio Grande do Sul $\left(29^{\circ}-32^{\circ} \mathrm{S}\right)$ is characteristically seasonal. Although births extend for five months, $75 \%$ of them take place between October and December. Very similar birth periods were found for franciscanas in Uruguay $\left(33^{\circ}-34^{\circ} \mathrm{S}\right)$ (November and December) (Harrison et al., 1981; Brownell, 1984) and in Paraná/southern São Paulo $\left(25^{\circ}\right.$ S) (October to December) (Rosas and Monteiro-Filho, 2001). On the other hand, Ramos (1997) noted the absence of seasonality in Rio de Janeiro $\left(21^{\circ} S\right)$, where births take place year around.

Among the factors that may influence the timing of reproduction in mammals are the availability and quality of food, variation in the predation pressure and variation in the environment temperature and photoperiod (e.g. Dobson and Kjelgaard, 1985; Rutberg, 1987; Bronson, 1989, 1995). Thus, the regional variance in franciscana reproductive seasonality may be the reflection of local differences in these factors. Although all these biotic and abiotic factors have the capacity to shape the seasonality of the franciscana reproduction, the available information on most of them is still scanty to allow a comparison between areas.

However, surface water temperature is a well-documented variable. The waters of Rio Grande do Sul experience considerable fluctuations in temperature (Figure 7), remaining around $15-16^{\circ} \mathrm{C}$ in the winter, rising to $20^{\circ} \mathrm{C}$ in mid spring, when the first calves are recorded, and reaching $26^{\circ} \mathrm{C}$ during the summer. Thus, franciscana parturition takes place during the months when the waters are warmer and more suitable for the birth and first months of growth of a calf, suggesting that the observed seasonality may have evolved, at least in part, as a response to the fluctuations of the environmental temperature. Oppositely, the fluctuation of the water temperature in the Rio de Janeiro coast is much less noteworthy. Sea-surface temperature variation along all the year in that region $\left(22-26^{\circ} \mathrm{C}\right)$ (Ramos, 1997) corresponds to the same range of temperatures that occur during the parturition months in Rio Grande do Sul $\left(20-26^{\circ} \mathrm{C}\right)$. In this sense, the energetic cost of maintaining the body heat is certainly reduced in franciscana calves from Rio de Janeiro, which allows the births to take place even during autumn and winter months. Further comparative analyses on other variables that can potentially influence the franciscana reproductive seasonality (e.g. food availability) are encouraged.

Collectively, the franciscana can be considered one of the cetaceans with fastest life history traits, mainly due to its remarkably low age at sexual maturity, short reproductive interval and short life span. Its age at sexual maturity is one of the earliest among the group (Danilewicz et al., 2000), resembling only those of the phocoenids harbour porpoise, Phocoena phocoena (Read and Hohn, 1995), Dall's porpoise, Phocoenoides dalli (Ferrero and Walker, 1999) and vaquita, Phocoena sinus (Hohn et al., 1996), and it is considerably lower than the ASMs of delphinids, even those with similar maximum observed age (e.g. Cephalorhynchus hectori - Slooten, 1991).

The ASM estimated here was the same as the one calculated by Danilewicz et al. (2000) for a smaller sample from Rio Grande do Sul. The youngest mature females were 3 years old, the same age of the youngest pregnant females $(n=5)$. This might suggest that some animals could have attained sexual maturity when they were 2 years old, although no females with this age in the sample $(n=11)$ were mature. When the conception dates of the fetuses of these females were estimated, it could be noticed that one female was fertilized before October, suggesting that this animal was still 2 years old when conceiving. Pinedo (1994) analyzed the age structure of animals from Rio Grande do Sul and Uruguay and also noticed one pregnant female aged 2 years. 


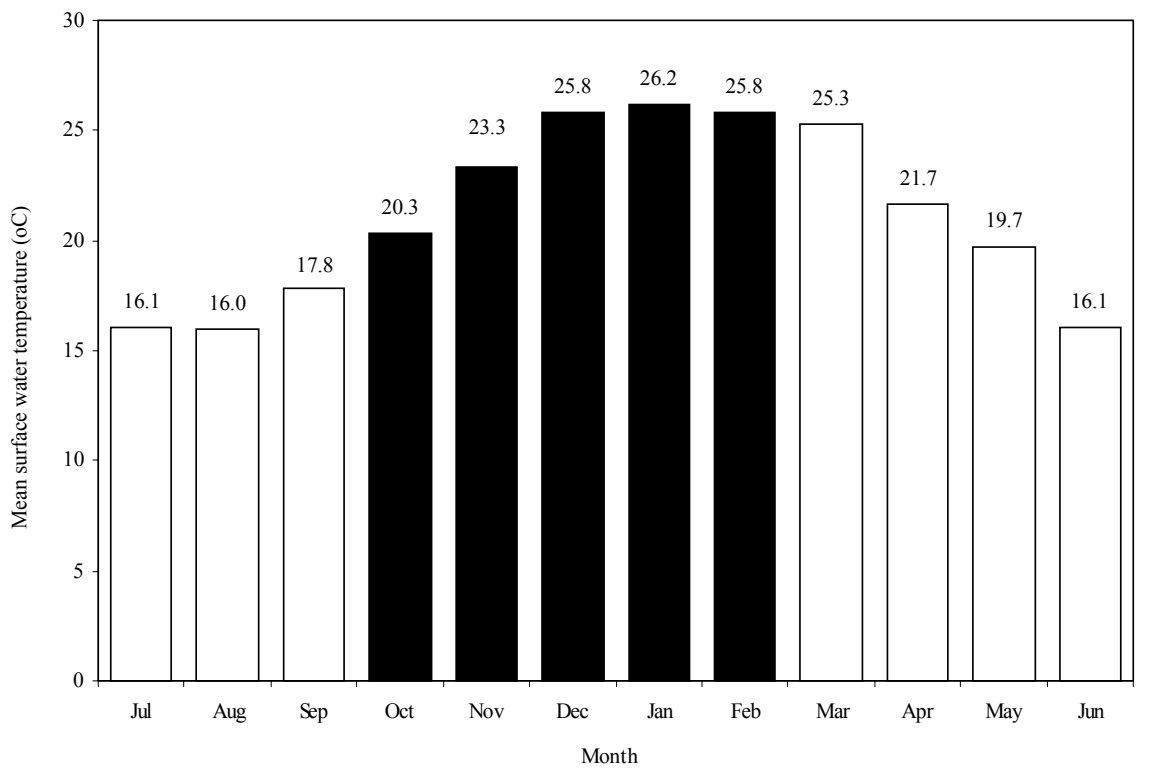

Figure 7. Monthly variation of the mean water surface temperature in the coast of Rio Grande do Sul (1994-1995). Black bars indicate the period when births of franciscanas, Pontoporia blainvillei, take place in the region.

The reproductive rates presented here are also very similar to those given by Danilewicz et al. (2000) for a smaller sample from Rio Grande do Sul. The APR found in this study indicates that about half of the mature females are reproducing annually, while other half are reproducing biannually [ 0.5 mature females $\times 1$ year $)+(0.5$ mature females $\times 2$ years $)=$ 1.5]. Consequently, the proportion of lactating $(0.30)$ and simultaneously pregnant and lactating females $(0.10)$ found here is lower than the expected for a mean calving interval of 1.5 years ( 0.5 lactating and 0.39 simultaneously pregnant and lactating). This low proportion of lactating females may be caused by sampling bias due to lower vulnerability to bycatch. Segregation in the geographic distribution between lactating and pregnant animals in Rio Grande do Sul may also affect the results. Further investigation on large- and small-scale habitat use of the franciscana in Rio Grande do Sul will assist in clarifying the effect of the species distribution on these parameter's estimations.

Amongst the five females with evidences of recent ovulation, two were collected in months (June and August) out of the main mating period (November to early March). Similarly, Danilewicz et al. (in press) did not found any regression in testis mass of mature males in non-reproductive months, concluding that males are able to produce spermatogonia and reproduce year-round. The presence of two fetuses displaced of the fetal growth curve indicates that some franciscanas mate and conceive out of the main mating period, although the viability of these calves potentially decreases.

There was no indication that female franciscanas experience reproductive senescence, as observed in some extended life span cetaceans, such as pilot whales (Marsh and Kasuya, 1984). The oldest known female and male franciscanas from Rio Grande do Sul and Uruguay are 21 and 15 years old, respectively (Pinedo, 1994), which led this author to comment that females seem to have a higher longevity than males. However, from the 374 franciscanas with known age and sex studied by Pinedo (1994), the proportion of the animals older than 12 years was $6.3 \%$ for the males and $3.0 \%$ for the females. Thus, it seems unlikely that there is a sexdifferential mortality for P. blainvillei.

Although there is evidence that some franciscanas are able to live until they are 20 years old, the large majority of animals do not seem to live more than 13-14 years. The high mortality in gillnets mainly of juveniles, together with the natural mortality by diseases and predation (Praderi, 1985; Ott and Danilewicz, 1998) indicates it is unlikely that adult franciscanas will reach maximum potential longevity. Similarly, Brownell (1984) suggests that the longevity of franciscana should be considered 15 years. Considering this information, and taking account the ASMs and the calving intervals presented here, it is suggested the one female franciscana may have 5-10 calves per lifetime (see Table 3).

Table 3. Suggested offspring size of franciscana, Pontoporia blainvillei, in Rio Grande do Sul, considering a life expectancy of 14 years, an age at sexual maturity of $3.7(95 \% \mathrm{CI}=3.0-4.4)$ and a calving interval of $1.5(95 \% \mathrm{CI}=1.2-2.1)$.

\begin{tabular}{ccc}
\hline \hline $\begin{array}{c}\text { AGE AT } \\
\text { SEXUAL MATURITY }\end{array}$ & $\begin{array}{c}\text { CALVING } \\
\text { INTERVAL }\end{array}$ & $\begin{array}{c}\text { OFFSPRING } \\
\text { SIZE }\end{array}$ \\
\hline \hline 3.0 & 1.2 & 10 \\
3.0 & 1.5 & 8 \\
3.0 & 2.1 & 6 \\
3.7 & 1.2 & 10 \\
3.7 & 1.5 & 7 \\
3.7 & 2.1 & 5 \\
4.4 & 1.2 & 9 \\
4.4 & 1.5 & 6 \\
4.4 & 2.1 & 5 \\
\hline \hline
\end{tabular}




\section{Acknowledgements}

I am very grateful to the fishermen from Tramandaí/Imbé and Rio Grande for their important cooperation with the franciscana projects during various years. I thank my many colleagues who participated in the collection and necropsies, including Ignacio Moreno, Paulo Ott, Márcio Martins, Glauco Caon, Larissa Oliveira, Edu Secchi, Manuela Bassoi, Alexandre Zerbini, Luciana Möller, Luciano Dalla Rosa, Lilia Fidelix and numerous volunteers. Nelson Fontoura has provided guidance and supervision in many steps of this study. Edu Secchi allowed me to use unpublished data. Gonad histology was carried out in Laboratório de Histologia e Embriologia Comparada of Universidade Federal do Rio Grande do Sul and I thank Prof. Sônia Garcia, Prof. Nívea Lothhammer and Eliane Borges for their instructions and encouragement on this subject. Paulo Ott, Edu Secchi, Enrique Crespo and Silvana Dans participated in the age determination procedures. Part of the age determination was also done in the Rio Grande and the author thanks Cristina Pinedo and Fernando Rosas for their kind teachings. Thanks also to Norma Luiza Würdig, Irajá Damiani Pinto (CECLIMAR-UFRGS) and Lauro Barcellos (Director of the Museu Oceanográfico) for the constant logistical support and encouragement of the marine mammal research in southern Brazil. Alessandra Higa provided data on the $50 \mathrm{~m}$ isobath presented in Figure 1. Márcio Martins, Ignacio Moreno, Luiz Malabarba and Mônica Muelbert improved an earlier version of this manuscript with their comments. Toshio Kasuya, Christina Lockyer and Edu Secchi kindly reviewed this paper and provided valuable suggestions. Financial support was given by the Cetacean Society International, Fundação O Boticário de Apoio à Natureza, The John \& Catherine MacCarthur Foundation, CNPq, United Nations Environmental Program, Yaqu Pacha Organization, and Whale and Dolphin Conservation Society. This article (GEMARS contribution $n^{\circ}$. 013) is part of D. Danilewicz's Master Thesis and the Coordenação de Aperfeiçoamento de Pessoal em Ensino Superior (CAPES) has granted him a graduate fellowship.

\section{References}

American Society of Mammalogists. (1961) Standardized methods for measuring and recording data on the smaller cetaceans. Journal of Mammalogy 42: 471-476.

Benirschke, K., Johnson, M.L. and Benirschke, R.J. (1980) Is ovulation in dolphins, Stenella longirostris and Stenella attenuata, always copulation-induced? Fishery Bulletin 782:507-528.

Boyd, I.L. (1984) Development and regression of the corpus luteum in the grey seal (Halichoerus grypus) ovaries and its use in determining fertility rates. Canadian Journal of Zoology 62: 1095-1100.

Brownell, R.L., Jr (1984) Review of reproduction in platanistid dolphins. Report of the International Whaling Commission (special issue) 6: 149-158.
Bronson, F.H. (1989) Mammalian Reproductive Biolology. The University of Chicago Press, Chicago.

Bronson, F.H. (1995) Seasonal variation in human reproduction: environmental factors. Quarterly Review of Biology 70 (2): 141-164.

Calder, W.A. (1982) The pace of growth: an allometric approach to comparative embryonic and post-embryonic growth. Journal of Zoology 198: 215-225.

Crespo, E.A., Harris, G. \& González, R. (1998) Group size and distribution range of the franciscana, Pontoporia blainvillei. Marine Mammal Science 14 (4): 845-849.

Danilewicz, D., Claver, J.A., Pérez-Carrera, A.L., Secchi, E.R. and Fontoura, N.F. (in press) Reproductive biology of male franciscanas (Pontoporia blainvillei) (Mammalia: Cetacea) from Rio Grande do Sul, southern Brazil. Fishery Bulletin.

Danilewicz, D., Secchi, E.R., Ott, P.H. and Moreno, I.B. (2000) Analyses of the age at sexual maturity and reproductive rates of franciscanas (Pontoporia blainvillei) from Rio Grande do Sul, southern Brazil. Comunicações do Museu de Ciências e Tecnologia da PUCRS. Série Zoologia 13: 89-98.

DeMaster, D. P. (1978) Calculation of the average age of sexual maturity in marine mammals. Journal of Fisheries and Research Board of Canada 35 (6):912-15.

Dobson, F.S. and Kjelgaard, J.D. (1985) The influence of food resources on life history in Columbian ground squirrels. Canadian Journal of Zoology 63: 2105-2109.

Ferrero R.C. and Walker, W.A. (1993) Growth and reproduction of the northern rigth whale dolphin, Lissodelphis borealis, in the offshore waters of the North Pacific Ocean. Canadian Journal of Zoology 71 (12): 2335-2344.

Ferrero, R.C. and Walker, W.A. (1999) Age, growth, and reproductive patterns of Dall's porpoise (Phocoenoides dalli) in the central North Pacific ocean. Marine Mammal Science 15 (2): 273-313.

Harrison, R.J. (1969). Reproduction and reproductive organs. In Andersen, H.T. (ed.). The biology of marine mammals. Academic Press.

Harrison, R.J., Bryden, M.M., McBrearty, D.A. and Brownell, R.L., Jr. (1981) The ovaries and reproduction in Pontoporia blainvillei (Cetacea:Platanistidae). Journal of Zoology 193: 563-580.

Hohn, A.A., Read, A., Fernandez, F., Vidal, O. and Findley, L.T. (1996) Life history of the vaquita, Phocoena sinus (Phocoenidae, Cetacea). Journal of Zoology 239: 235-251.

Huggett, A., St. G. and Widdas, W.F. (1951) The relationship between the mammalian foetal weight and conception age. Journal of Physiology 114: 306-317.

Iwasa, M. and Atkinson, S. (1996) Analysis of corpora lutea to estimate reproductive cycles of wild Hawaiian monk seals (Monachus schauinslandi). Marine Mammal Science 12 (2):182-198.

Kasuya, T. (1977) Age determination and growth of the Baird's beaked whale with a comment on the fetal growth rate. Scientific Report of the Whales Research Institute 29: 1-20.

Kasuya, T. and Brownell, R.L., Jr. (1979) Age determination, reproduction, and growth of the franciscana dolphin, Pontoporia blainvillei. Scientific Report of the Whales Research Institute 31: 45-67.

Kasuya, T. and Marsh, H. (1984). Life history and reproductive biology of the short-finned pilot whale, 
Globicephala macrorhynchus, off the Pacific coast of Japan. Rep. Int Whal. Commn. (special issue) 6: 259-310.

Kiltie, R.A. (1982) Intraspecific variation in mammalian gestation period. Journal of Mammalogy 63: 646-652.

Lockyer, C. (1984). Review of baleen whale (Mysticeti) reproduction and implications for management. Report of the International Whaling Commission (special issue) 6: $27-48$

Majluf, P. (1992) Timing of births and juvenile mortality in the south American fur seal in Peru. Journal of Zoology 227: 367-383.

Marsh, H. and Kasuya, T. (1984) Changes in the ovaries of the short-finned pilot whale, Globicephala macrorhynchus, with age and reproductive activity. Report of the International Whaling Commission. (special issue 12) 6: 311-335.

Miyazaki, N. (1977) Growth and reproduction of Stenella coeruleoalba off the Pacific coast of Japan. Scientific Report of the Whales Research Institute 29: 21-48.

Moreno, I.B., Ott, P.H. and Danilewicz, D. (1997) Análise preliminar do impacto da pesca artesanal costeira sobre Pontoporia blainvillei no litoral norte do Rio Grande do Sul, sul do Brasil. P. 31-41. in: Pinedo, M.C. and Barreto, A. (Eds) Proceedings of the Second Workshop for the Research Coordination and Conservation of the Franciscana (Pontoporia blainvillei) in the Southwestern Atlantic. Rio Grande. 88p.

Ott, P.H. and Danilewicz, D. (1998) Presence of franciscana dolphins (Pontoporia blainvillei) in the stomach of a killer whale (Orcinus orca) stranded in southern Brazil. Mammalia. 62 (4): 605-609.

Ott, P.H. (1998) Análise das capturas acidentais da toninha, Pontoporia blainvillei, no litoral norte do Rio Grande do Sul, sul do Brasil. Master Dissertation, Pontifícia Universidade Católica do Rio Grande do Sul, Porto Alegre. 120pp.

Ott, P.H., Secchi, E.R., Moreno, I.B., Danilewicz, D., Crespo, E.A., Bordino, P., Ramos, R., Di Beneditto, A.P., Bertozzi, C., Bastida, R., Zanelatto, R., Perez, J. and Kinas, P.G. (2002) Report of the working group of fishery interactions. Latin American Journal of Aquatic Mammals (special issue) 1: 55-64.

Perrin, W.F., Coe, J.M., and Zweifel, J.R. (1976) Growth and reproduction of the spotted porpoise, Stenella attenuata, in the offshore eastern tropical Pacific. Fishery Bulletin 74: 229-269.

Perrin, W.F., Holts, D.B., and Miller, R.B. (1977) Growth and reproduction of the eastern spinner dolphin, a geographical form of Stenella longirostris in the eastern tropical Pacific. Fishery Bulletin 75: 725-750.

Perrin, W.F. and Donovan, G.P. (1984) Report of the workshop. Report of the International Whaling Commission (special issue 6): 1-24.

Perrin, W.F. and Reilly, S.B. (1984) Reproductive parameters of dolphins and small whales of the family Delphinidae. Report of the International Whaling Commission (special issue 6): 97-133.

Pinedo, M.C. (1991) Development and variation of the franciscana, Pontoporia blainvillei. Doctoral Thesis. Santa Cruz. University of California. $406 \mathrm{p}$.

Pinedo, M.C. (1994) Impact of incidental fishery mortality on the age structure of Pontoporia blainvillei in southern Brazil and Uruguay. Report of the International Whaling Commission. (special issue 15): 261-264.
Pinedo, M.C. and Barreto, A. (eds) (1997) Proceedings of the Second Workshop for the Research Coordination and Conservation of the Franciscana (Pontoporia blainvillei) in the Southwestern Atlantic. Rio Grande. 88p.

Pinedo, M.C. and Hohn, A. (2000) Growth layer patterns in teeth from the franciscana, Pontoporia blainvillei: developing a model for precision in age estimation. Marine Mammal Science 16 (1): 1-27.

Praderi, R. (1985) Relaciones entre Pontoporia blainvillei (Mammalia: Cetacea) e tiburones (Selachii) de aguas Uruguaias . Comunicaciones Zoologicas Museu de Historia Natatural de Montevideo. 11 (151): 1-19.

Praderi, R., Pinedo, M.C. and Crespo, E.A. (1989) Conservation and management of Pontoporia blainvillei in Uruguay, Brazil and Argentina. In: Perrin, W.F., Brownell, R.L., Zhou Kaya, Liu Jiankang (eds.). Biology and Conservation of River Dolphins, p. 52-56.

Ramos, R.M.A. (1997) Determinação de idade e biologia reprodutiva de Pontoporia blainvillei e da forma marinha de Sotalia fluviatilis no litoral norte do Rio de Janeiro. Dissertação de Mestrado. Rio de Janeiro. Universidade Estadual do Norte Fluminense. 95p.

Ramos, R.M.A., Di Beneditto, A.P.M. and Lima, N.R.W. (2000) Growth parameters of Pontoporia blainvillei and Sotalia fluviatilis (Cetacea) in northern Rio de Janeiro, Brazil. Aquatic Mammals 26 (1): 65-75.

Read, A. and Hohn, A. (1995) Life in the fast lane: the life history of the harbour porpoises from the Gulf of Maine. Marine Mammal Science 11: 423-440.

Rosas, F.C.W. and Monteiro-Filho, E.L.A. (2001) Reproductive parameters of Pontoporia blainvillei (Cetacea, Pontoporidae), on the coast of São Paulo and Paraná States, Brazil. Mammalia 66 (2): 231-245.

Rutberg, A.T. (1987) Adaptative hypotheses of birth synchrony in ruminants: an interspecific test. American Naturalist 130: 692-710.

Secchi, E.R. (1999) Taxa de crescimento potencial intrínseco de um estoque de franciscanas, Pontoporia blainvillei (Gervais E D'Orbigny, 1846) (Cetacea, Pontoporiidae) sob o impacto da pesca costeira de emalhe. Master Thesis, Fundação Universidade do Rio Grande, Rio Grande.152pp.

Secchi, E.R., Zerbini, A.N., Bassoi, M., Dalla Rosa, L., Moller, L.M. and Rocha-Campos, C.C. (1997) Mortality of franciscanas, Pontoporia blainvillei, in coastal gillnetting in southern Brazil. Report of the International Whaling Commission 47: 653-658.

Secchi, E. R., Ott, P. H., and Danilewicz, D. (2002) Report of the fourth workshop for the coordinated research and conservation of the franciscana dolphin (Pontoporia blainvillei) in the western South Atlantic. The Latin American Journal of Aquatic Mammals (special issue) 1:11-20.

Secchi, E.R., Ott, P.H. and Danilewicz, D. (2003) Effects of fishing bycatch and the conservation status of the franciscana dolphin, Pontoporia blainvillei. Pages 174191 in Gales N., Hindell, M. and Kirkwood, R. (Eds) Marine Mammals: Fisheries, Tourism and Management Issues. SCIRO Publishing. Collingwood. Australia.

Siciliano, S., Di Beneditto, A.P. and Ramos, R.M.A. (2002) A toninha, Pontoporia blainvillei (Gervais \& d'Orbigny, 1844) (Mammalia, Cetacea, Pontoporiidae), nos estados do Rio de Janeiro e Espírito Santo, costa 
sudeste do Brasil: caracterizaçoes dos habitats e fatores de isolamenta das populaçoes. Boletim do Museu Nacional, Zooogia. 476:1-15.

Slooten, E. (1991) Age, growth, and reproduction in Hector's dolphins. Canadian Journal of Zoology 69: 1689-1700.
Walter, T. (1997) Curvas de crescimento aplicadas a organismos aquáticos. Um estudo de caso para a toninha, Pontoporia blainvillei (Cetacea, Pontoporiidae) do extremo sul do Brasil. Bachelor Dissertation, Fundação Universidade do Rio Grande, Rio Grande. 102pp. 